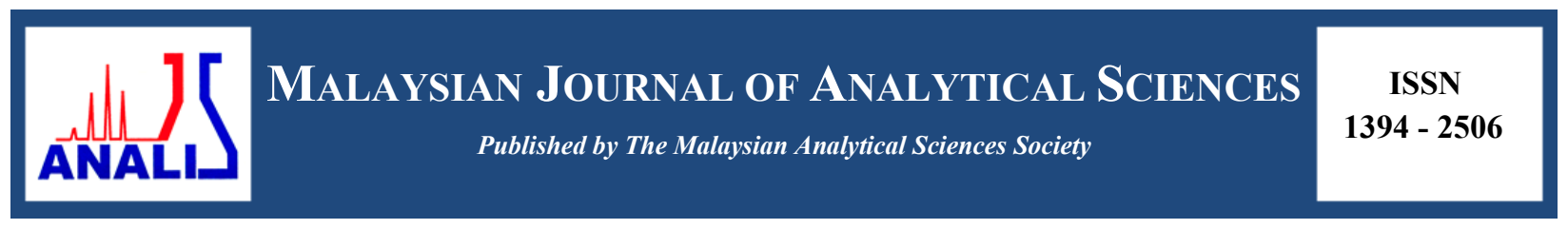

\title{
LIQUID MEMBRANE COMPONENT SELECTION FOR REMOVAL OF PHENOL FROM SIMULATED AQUEOUS WASTE SOLUTION
}

\author{
(Pemilihan Komponen Cecair Membran untuk Pembuangan Fenol daripada Air Sisa) \\ Muhammad Bukhari Rosly ${ }^{1}$, Norasikin Othman ${ }^{1,2 *}$, Hilmi Abdul Rahman ${ }^{1}$ \\ ${ }^{I}$ Department of Chemical Engineering, Faculty of Chemical and Energy Engineering \\ ${ }^{2}$ Centre of Lipid Engineering and Applied Research, Ibnu Sina Institute of Scientific and Industrial Research \\ Universiti Teknologi Malaysia, 81310 UTM Skudai, Johor, Malaysia \\ *Corresponding author: norasikin@cheme.utm.my
}

Received: 16 April 2017; Accepted: 7 March 2018

\begin{abstract}
Phenol is considered as one of the environmental pollutants in various industrial effluents that needs to be removed. One of the potential methods for the removal and recovery of phenol is the emulsion liquid membrane (ELM) process. In order to prepare a stable and efficient emulsion liquid membrane, selecting the components of the membrane is crucial to the process development. This research was conducted to investigate the feasibility of palm oil as an organic solvent in liquid membrane (LM) formulation for phenol extraction and to study the effects of several parameters which affect the extraction and recovery performance of phenol using liquid-liquid extraction. The feasibility of palm oil was investigated by manipulating the organic solvent used, either palm oil or a mixture of palm oil and kerosene. Several parameters such as type of carrier, carrier concentration, type of stripping agent and stripping agent concentration were varied during LM component selection. The results showed that mixed palm oil and kerosene provides a high potential as an organic solvent for the extraction of phenol. About $71 \%$ of phenol was extracted at a palm oil to kerosene ratio of 70:30 and assisted with shorter time of phase separation between loaded organic and phenol feed phase. The addition of $0.1 \mathrm{M}$ of TBP (tributyl phosphate) as a carrier increased the extraction of phenol to $86 \%$ and prevented the third phase formation. Meanwhile, $2 \mathrm{M}$ of sodium hydroxide was able to act as a stripping agent to recover $81 \%$ of the phenol from the overall process. It can be concluded that palm oil has shown great potential in extracting phenol and could be applied in an ELM process as a green solvent for an emulsion liquid membrane process.
\end{abstract}

Keywords: phenol, wastewater, liquid membrane components selection, liquid-liquid extraction, organic solvent

\begin{abstract}
Abstrak
Fenol dipertimbangkan sebagai salah satu bahan pencemar daripada air sisa buangan industri yang perlu dirawat. Salah satu kaedah yang berpotensi untuk penyingkiran dan pemulihan fenol adalah proses emulsi membran cecair (ELM). Pemilihan komponen membran adalah penting untuk membentuk emulsi membran cecair yang stabil dan cekap. Kajian ini dijalankan untuk mengkaji kebolehan minyak kelapa sawit sebagai pelarut organik dalam membran cecair (LM) untuk pengekstrakan fenol dan untuk mengkaji kesan terhadap beberapa parameter yang mempengaruhi pengekstrakan dan pemulihan fenol menggunakan pengekstrakan cecair-cecair. Kesesuaian minyak kelapa sawit dikaji dengan memanipulasi pelarut organik yang digunakan, sama ada minyak kelapa sawit atau campuran minyak kelapa sawit dan kerosin. Beberapa parameter seperti jenis pembawa, kepekatan pembawa, jenis agen pelucut dan kepekatan agen pelucut diubah semasa pemilihan komponen LM. Keputusan menunjukkan bahawa campuran minyak sawit dan kerosin berpotensi tinggi sebagai pelarut organik dalam pengekstrakan fenol. Kira-kira $71 \%$ fenol diekstrak oleh campuran minyak kelapa sawit dan kerosin yang bernisbah 70:30 dengan kadar masa pemisahan fasa yang lebih pendek di antara fasa organik yang mempunyai fenol dan fasa suapan. Penambahan 0.1M TBP (tributil fosfat) sebagai pembawa meningkatkan pengekstrakan fenol kepada $86 \%$ dan menghalang pembentukan fasa ketiga. Sementara itu, $2 \mathrm{M}$ natrium hidroksida mampu bertindak sebagai agen pelucutan untuk mendapatkan $81 \%$ daripada fenol daripada keseluruhan proses. Dapat
\end{abstract}


disimpulkan bahawa minyak sawit telah menunjukkan potensi yang besar dalam mengekstrak fenol dan boleh digunakan dalam proses ELM sebagai pelarut hijau untuk proses emulsi membran cecair.

Kata kunci: fenol, air sisa, pemilihan komponen membran cecair, pengekstrakan cecair-cecair, pelarut organik

\section{Introduction}

Phenol is a colourless crystalline aromatic alcohol which has a sweet odour. Due to its ability to form hydrogen bonds with other molecules, phenol is soluble in water and can dissolve in most organic solvents, such as aromatic hydrocarbons, halogenated hydrocarbons, ketones, ethers, alcohols and acids [1]. Thus, phenolic compounds are considered as valuable chemical products in various applications such as adhesives, dyes, germicides and chemical intermediates [2]. Unfortunately, phenol pollution can threaten the environment which includes the flora and fauna, and human health $[3,4]$. Phenol is classified as corrosive and toxic and can be very dangerous if it is overexposed. Phenol exists in industrial effluents especially from petrochemical industries, refineries, paints and pharmaceuticals. The concentration of phenol present in wastewater from the industries is $6-500 \mathrm{mg} / \mathrm{L}$ for refineries, $28-3900 \mathrm{mg} / \mathrm{L}$ for coal processing and 2.8-1220 mg/L for petrochemical plants while pharmaceuticals, paints, plastics, pulp, wood products and paper industries contain $0.1-1600 \mathrm{mg} / \mathrm{L}$ of phenol [5]. Therefore, the treatment of wastewaters containing phenol before they are discharged has become the recent major concern.

There are various techniques of phenol removal and recovery which can be classified into traditional, and advanced techniques. The traditional techniques incorporate adsorption, liquid-liquid extraction (LLE), steam distillation, chemical oxidation, and biodegradation, while the advanced techniques incorporate photo oxidation processes and membrane separation technologies [2]. Basically, the feasibility of the separation techniques is revised according to the type of wastewater, wastewater composition, treatment efficiency, and operation costs. The most common process for phenol removal is adsorption [6]. A study shows that the use of one of the zeolitic imidazolate frameworks (ZIFs), as an absorbent in phenol removal promotes high adsorption capacity of phenol [7]. However, the difficulties in the recovering of the adsorbent such as activated carbon from treated water and high costs have become major disadvantages of the adsorption process. Besides, another technique in phenol removal and recovery, which is ultrafiltration has been studied by many researchers [8, 9]. The problem regarding this technique is it is incapable to remove small molecular weights of metal ions and organic solutes such as phenol where ultrafiltration systems with many tiny pore membrane size is required to remove small molecular weights metal ions or organic pollutants and this will significantly increase the capital and operating costs [8]. Liquid-liquid extraction is also one of the phenol removal techniques. However, the use of petroleum-based solvents such as kerosene, benzene and toluene are limited because of their high flammability and toxicity [10].

There are many advantages of the emulsion liquid membrane (ELM) process for the removal of phenolic compounds which is high selectivity, high flux ratio, recyclable organic solvents, promising green solvents or carriers, a single stage extraction process and treatment of multiple mixtures in the effluent [11]. In ELM, the emulsion droplets are formed through the emulsification of a stripping agent and a liquid organic solvent. The emulsion droplets are then dispersed into the feed phase for the permeation of solute to take place. The transfer of solute from the feed phase across the membrane phase into the receiving phase is a mass transfer process [12]. The accessibility of this technique basically depends on the emulsion's stability and the ability of solutes to transport across the membrane. Thus, LM component selection is crucial in determining the efficiency of solutes transport. Basically, the step was carried out using liquid-liquid extraction (LLE) for the selection of organic solvents (diluent), carriers and stripping agents $[13,14]$.

In this study, the efficiency of the combination of palm oil as an organic solvent and kerosene to extract phenol from simulated wastewater was investigated. The efficiency of extraction and the recovery performance were studied throughout the liquid-liquid extraction process.

\section{Chemicals and reagents}

\section{Materials and Methods}

All reagents used were of analytical grade and were used without further purification. Palm cooking oil was purchased from the supermarket, while kerosene and phenol were purchased from Sigma-Aldrich. For stripping 
agents, acidic thiourea (assay: 99\%) was obtained from Qrec, sodium hydroxide (assay: 99\%) was obtained from Merck, hydrochloric and sulphuric acids (assay: 97\%) were obtained from JT Baker.

\section{Experimental procedures: Preparation of phenol solution}

The phenol feed stock aqueous solution $(300 \mathrm{ppm})$ was prepared by dissolving the required quantity of crystallized phenol in distilled water. For calibration, the $300 \mathrm{ppm}$ phenol was diluted to 5, 10, 15, 20, 25 and $30 \mathrm{ppm}$. UVspectrophotometer was used to measure the contents of phenol in wastewater at wavelength, $\lambda$ of $270 \mathrm{~nm}$.

\section{Extraction and stripping process}

An equal volume of the feed phase of phenol waste and organic membrane solutions $(100 \mathrm{ml})$ were mixed in a beaker and stirred at $150 \mathrm{rpm}$ for 1 hour. After the extraction process, the solution was transferred into a separating funnel and was left for 15 minutes for phase separation. The treated aqueous phase was carefully separated from the organic phase and the concentration of phenol in the liquid phase was measured using the UV-spectrophotometer. The concentration of phenol extracted in the organic membrane phase was calculated based on mass balance principles. The organic solutions that were used in the process were in various ratio of palm oil to kerosene (10:0, $9: 1,8: 2,7: 3,6: 4,5: 5$ and $0: 10)$.

The selection of carrier was conducted after finding the optimum composition of palm oil to kerosene. The liquidliquid extraction process was repeated by adding a carrier into the diluent. The steps were repeated for different types of carrier such as TOA (trioctylamine), TDA (tridecylamine), TBP (tributylphosphate), D2EPHA (bis-2ethylhexyl phosphate) and Cyanex 302. After the most suitable carrier was obtained, the extraction process was repeated by varying the concentrations of the selected carrier.

The stripping process was carried out after the extraction process. An equal volume of phenol loaded membrane phase and stripping agent at a specific concentration $(100 \mathrm{ml})$ were stirred at $150 \mathrm{rpm}$ for 1 hour and then the sample was slowly poured into a separating funnel and left for phase separation for 15 minutes. After that, the liquid phase was separated from the organic phase and the concentration of phenol stripped was measured. These procedures were repeated for other stripping agents and concentrations. The stripping agents used were hydrochloric acid, sodium hydroxide, sulphuric acid and thiourea. This study was conducted at room temperature $\left(25 \pm 1{ }^{\circ} \mathrm{C}\right)$.

\section{Emulsion liquid membrane (ELM) process}

The ELM process was carried out after the selection of liquid membrane component completed. In this study, no carrier has been added in the organic phase because there was no significant result of phenol extraction during the LLE process. All optimum parameters for the ELM process were obtained from our previous work [15]. The w/o emulsion was prepared by mixing an organic liquid membrane containing 3\% of Span 80 with a stripping agent. A $7.5 \mathrm{ml}$ organic phase and a $2.5 \mathrm{ml}$ stripping phase (ratio of solvent to stripping phase; 3: 1) were emulsified continuously using homogenizer at $8000 \mathrm{rpm}$ for 5 minutes. Then, the $10 \mathrm{ml}$ prepared w/o emulsion was dispersed into $100 \mathrm{ml}$ of $100 \mathrm{ppm}$ of phenol (treat ratio; 1:10). The solution was stirred at $500 \mathrm{rpm}$ agitation speed using a digital mixer for 5 minutes. After the extraction process, the solution was immediately poured into a separating funnel and was left for 15 minutes for the phase separation of emulsion and external phase. The treated phenol solution (external phase) was taken for phenol content analysis using the UV-Spectrophotometer.

\section{Analytical procedures}

The percentage of extraction (E), percentage of stripping (S), percentage of recovery (R), and distribution ratio (D) were calculated using the following equations:

$$
\begin{aligned}
& \mathrm{E}(\%)=\frac{[\text { phenol] } \mathrm{i}-[\mathrm{phenol]}}{[\text { phenol] } \mathrm{i}} \times 100 \\
& \mathrm{~S}(\%)=\frac{[\text { phenol] strip }}{[\text { phenol] } \mathrm{org}} \times 100 \\
& \mathrm{R}(\%)=\frac{[\text { phenol] strip }}{[\text { phenol] } \mathrm{i}} \times 100
\end{aligned}
$$




$$
\mathrm{D}=\frac{[\text { phenol] org }}{[\text { phenol] } \mathrm{f}}
$$

where $[\text { phenol }]_{\mathrm{i}}$ is the initial phenol concentration in the aqueous phase $(\mathrm{mg} / \mathrm{L})$, [phenol $]_{\mathrm{f}}$ is the phenol concentration in the aqueous phase after extraction $(\mathrm{mg} / \mathrm{L}),[\mathrm{phenol}]_{\text {org }}$ is the phenol concentration in the organic phase $(\mathrm{mg} / \mathrm{L})$, and $[\mathrm{phenol}]_{\text {strip }}$ is the phenol concentration in the stripping phase.

\section{Effect of solvent type and composition on phenol extraction}

\section{Results and Discussion}

Figure 1 shows the effect of the organic solvent used in the extraction of phenol. The results reveal that the highest extraction of phenol using a $100 \%$ of kerosene and palm oil were $21 \%$ and $79 \%$ respectively at 1 hour of extraction time. The results show that an aliphatic hydrocarbon such as kerosene contributes to the lower extraction of phenol. This is because aliphatic hydrocarbon structures form long carbon chains which have non-polar properties. This means that kerosene cannot form any chemical reaction with the polar phenol. The transport mechanism of phenol in kerosene is only through the diffusion of the solutes into the membrane [16]. Thus, the diffusivity of phenol into kerosene is restricted by the solubility of phenol in water. Based on the properties of phenol, phenol is more soluble in water due to the hydrogen bonds and is less soluble in aliphatic hydrocarbons such as kerosene [1]. The use of kerosene as a liquid membrane basically assisted the addition of carriers to form complexes with the selective solutes. Meanwhile, the result shows a potential extraction efficiency of phenol using palm oil as a solvent. Palm oil contains triglycerides that are formed from the reaction of glycerol and ester molecules. Even though palm oil has non-polar properties, the triglycerides present in palm oil could help with the formation of phenol-triglycerides complexes either through hydrogen bonding or through intermolecular interaction between the molecules [15]. The transport mechanism of phenol can be explained by partitioning (dissolving) and complexation [16]. Also, the hydrophobic property of oils can dissolve phenolic compounds and the emulsion stability can generally be increased as palm oil provides high viscosity [17].

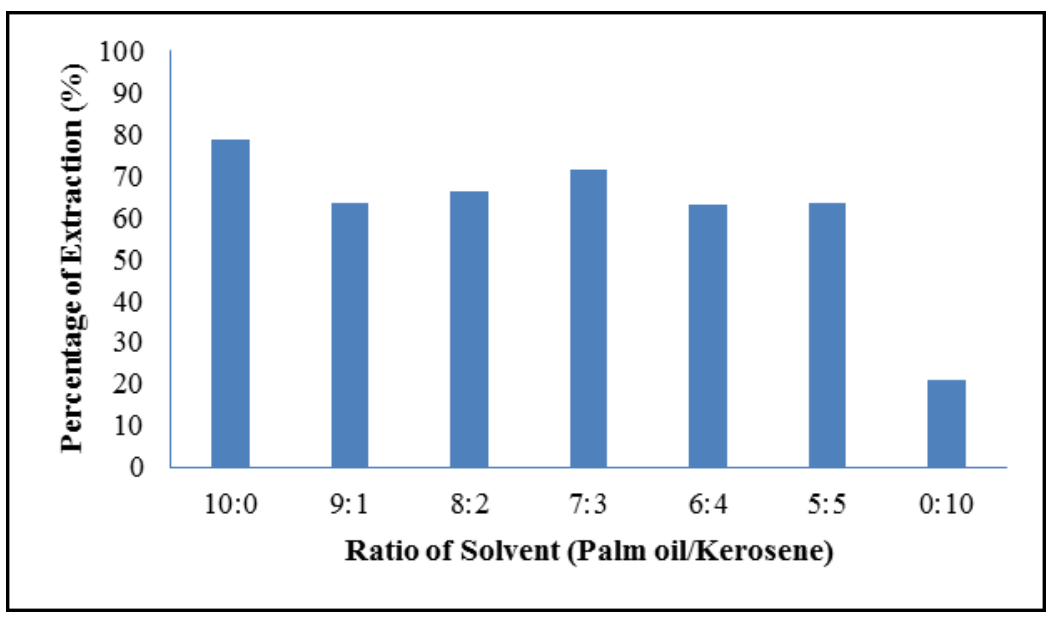

Figure 1. Extraction performance on difference ratio of palm oil to kerosene (Experiment conditions: [phenol] $=$ $300 \mathrm{ppm}$, rotation speed $=150 \mathrm{rpm}$, duration $=1 \mathrm{hr}$, temperature $=25 \pm 1{ }^{\circ} \mathrm{C}$, feed to solvent ratio $=1: 1$ )

However, the use of palm oil that resulted in the formation of a milky-like solution caused the phase separation of loaded organic and treated aqueous phase to become much slower. To improve the phase separation time, extractions using mixtures of palm oil and kerosene was carried out. The composition of the solvents that were investigated were in the ratio of $9: 1,8: 2,7: 3,6: 4$, and $5: 5$ of palm oil to kerosene. Based on Figure 1, 7:3 palm oil to kerosene ratio provided the highest phenol extraction compared to other ratio at $71 \%$ extraction efficiency. Also, it is observed that at this ratio the phase separation time of the mixed solution is significantly reduced. It is expected that by adding kerosene to palm oil, the viscosity of palm oil will be reduced hence it will increase the distribution 
coefficient of solutes and will influence the solvent extraction kinetics [10]. This is because kerosene contains a higher number of carbon atoms, which resulted in higher hydrophobicity and it is much less soluble in water compared to palm oil [18]. Therefore, by mixing the solvents between palm oil and kerosene, the transport mechanism of the phenol into the mixture can be explained by subsequent dissolving, complexation, and diffusion. The lower extraction of phenol at ratio of palm oil to kerosene of 9:1 and 8:2 can be explained by the stable resonance of phenol in the system [19]. Meanwhile, the lower extraction of phenol at ratio of palm oil to kerosene of 6:4 and 5:5 can be explained by the non-polar aliphatic hydrocarbon of kerosene in the system. Furthermore, the performance of the solvent can be increased by adding modifiers such as carriers and ionic liquids to prevent the formation of a third phase, to improve the solvent properties and to enhance the extraction efficiency. The 7:3 ration was used further in the study.

\section{Effect of carrier type on phenol extraction}

Selective carrier toward the solute plays an important role to enhance the extraction efficiency of the system. To increase the extraction of phenol, the selection of carriers is important. The aqueous solute phenol molecules will bind to the selective carriers and form complexes, thus increasing the solubility of phenol in the organic solvent. Also, a suitable carrier will be able to prevent the formation of a third phase which is due to the reaction of triglycerides and phenol molecules. Five types of carriers were investigated to extract phenol from aqueous solutions such as TOA (trioctyl amine), TDA (tridecyl amine), TBP (tributyl phosphate), D2EPHA (bis-2ethylhexyl phosphate) and Cyanex 302. Figure 2 shows the extraction efficiency of phenol using $0.05 \mathrm{M}$ carrier concentration. The results indicate that the highest extraction percentage of phenol was achieved when TBP was used as the carrier, which is at $77 \%$ and no third phase was observed. On the other hand, the extraction of phenol using TOA, TDA, D2EPHA and Cyanex 302 was lower due to weak molecular interactions. These results were in agreement with Zidi et al. [20] which reported that phenol can be efficiently extracted using various basic and solvating reagents due to the polarity of phenol.

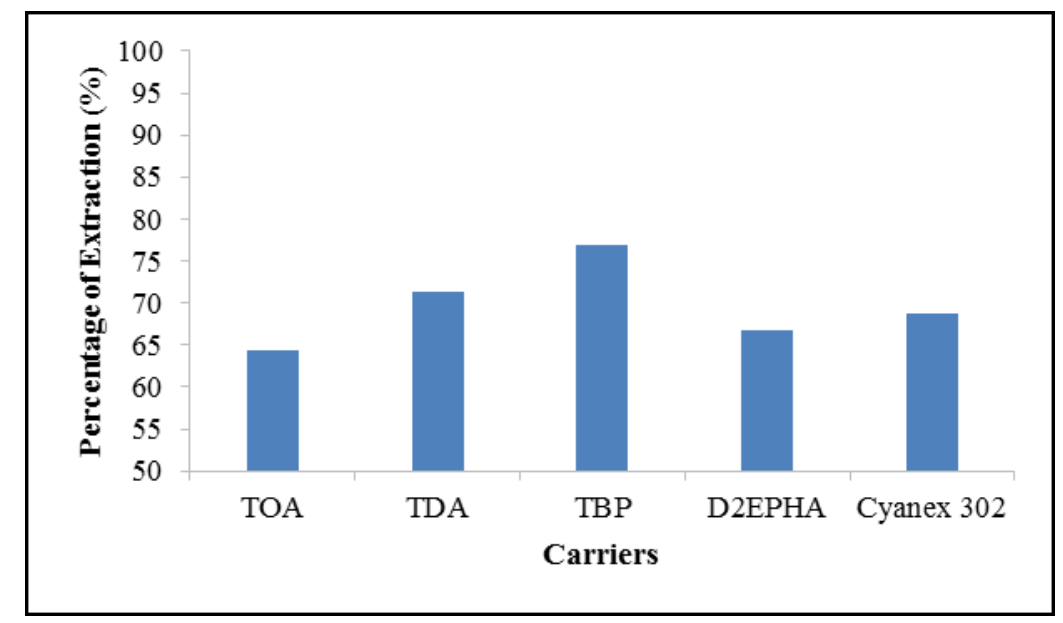

Figure 2. Liquid-liquid extraction of phenol using various carrier (experimental condition: Solvent $=7: 3$ of palm oil to kerosene ratio, $[\mathrm{PhOH}]=300 \mathrm{ppm}$, $[\mathrm{carrier}]=0.05 \mathrm{M}$, solvent $=7: 3$ palm oil to kerosene ratio, rotation speed $=150 \mathrm{rpm}$, duration $=1$ hour, $\mathrm{T}=25 \pm 1^{\circ} \mathrm{C}$ )

TBP as a solvating reagent has achieved the highest percentage of extraction due to its ability to react with polar phenol molecules and to be dissolved into solvents. This indicates that TBP has an ability to enhance the extraction of phenol using palm oil as a solvent. The extraction mechanism can be explained by the diffusion of phenol in aqueous solution from bulk to the interface where the reaction of phenol takes place with TBP present in the organic to form phenol-TBP complex by hydrogen bonding or intermolecular interactions between them. Zidi et al. [20] described the extraction of the phenol complex into the organic phase is based on the availability and the extractable phenol complex species formation due to transport flux. The presence of oxygen atoms in TBP (Figure 3) to form 
strong hydrogen bonds with phenol molecules provided a synergistic effect, thus enhancing the extraction efficiency. The reaction of phenol and TBP is considered reversible throughout the process as described in equation 5 below [21].

$$
\mathrm{PhOH}_{(\mathrm{aq})}+\mathrm{TBP}_{(\mathrm{org})} \leftrightarrow(\mathrm{PhOH} . \mathrm{TBP})_{(\mathrm{org})}
$$

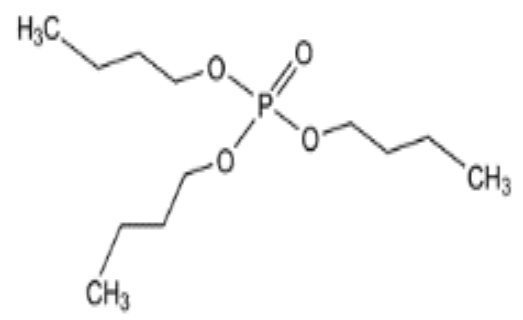

Figure 3. Molecular structure of tributyl phosphate (TBP)

\section{Effect of carrier concentration}

Figure 4 shows the result of phenol extraction in the range of $0.05 \mathrm{M}$ to $0.15 \mathrm{M}$ of TBP concentration. The result shows that the extraction percentage increases gradually and proportionally to carrier concentration from $0.05 \mathrm{M}$ to $0.1 \mathrm{M}$. Basically, with the increase of TBP concentration, there are more phenol-TBP complexes that can be formed during the process. The highest extraction percentage of phenol is $86 \%$ at $0.1 \mathrm{M}$ of TBP concentration. Further increase of the concentration of TBP resulted in a plateau where the extraction was in excess of the carriers. It indicates that the saturation capacity of the solvent phase for the phenol-TBP complexes has reached its peak at $0.1 \mathrm{M}$ TBP concentration. There were no significant effects with further increments of carrier concentration. In this study, $0.1 \mathrm{M}$ TBP was chosen as the optimum concentration of carrier because any further increase of the carrier concentration is expected to increase the solvent viscosity, which in turn affect the transport mechanism of phenol molecules due to high viscosity.

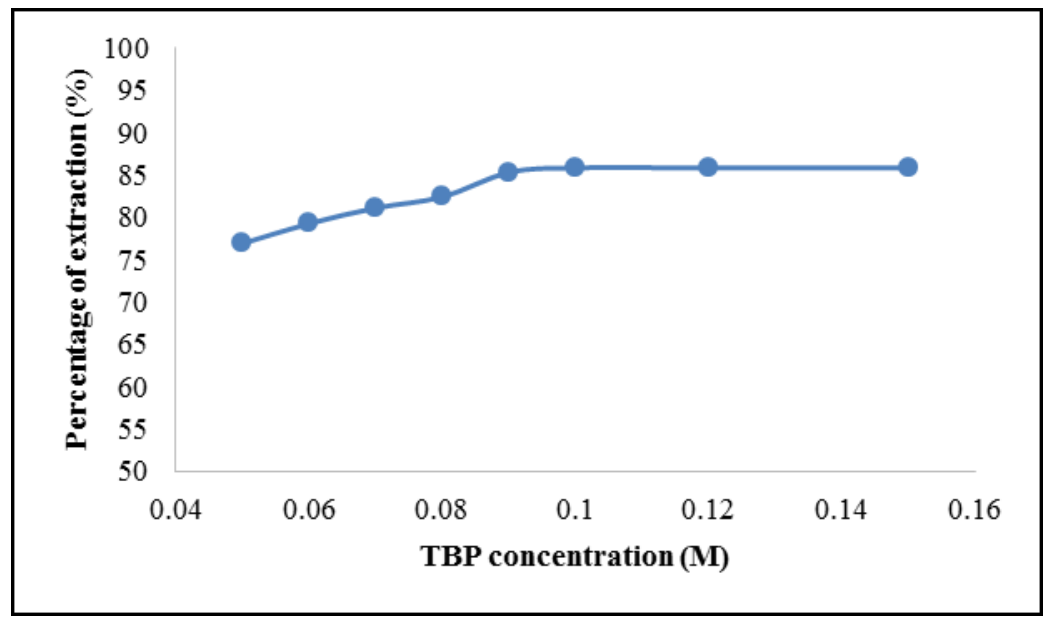

Figure 4. Effect of carrier concentration in liquid-liquid extraction of phenol (experimental condition: Solvent= $7: 3$ of palm oil to kerosene ratio, $[\mathrm{PhOH}]=300 \mathrm{ppm}$, carrier $=\mathrm{TBP}$, rotation speed $=150 \mathrm{rpm}$, duration $=1$ hour, $\mathrm{T}=25 \pm 1{ }^{\circ} \mathrm{C}$ )

According to Othman et al. [22], the nature of the extracted phenol was determined by plotting a graph of $\log \mathrm{D}$ versus $\log [\mathrm{TBP}]$ as shown in Figure 5. The slope of the line was used to determine the molar ratio of phenol reacting to TBP. The result shows that the distribution ratio of phenol increases with the carrier concentration in the 
organic phase. The result gives a straight line with a slope value of 0.9 which is close to unity. Thus, the molar ratio of phenol to TBP can be assumed to be 1:1. This indicates that one mole of phenol requires one mole of TBP for the reaction to form phenol-TBP complexes in the extraction process. The result confirms that TBP is effective in extracting cationic phenols even though palm oil was used as a diluent. However, in this preliminary emulsion liquid membrane process, the addition of TBP as a carrier was not considered since there is no significant result in phenol extraction throughout the process.

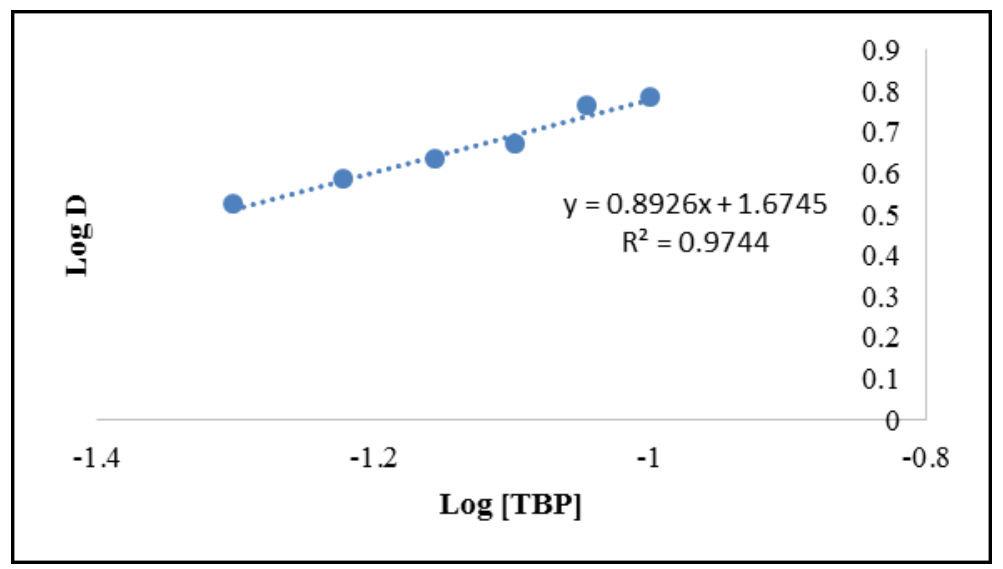

Figure 5. Stoichiometric plot for the equilibrium extraction of phenol using TBP as carrier

\section{Effect of stripping agents type in stripping process}

Stripping agents are a very important factor for solute recovery purposes. Various types of stripping agents at $0.5 \mathrm{M}$ concentration such as sodium hydroxide, sodium bicarbonate, hydrochloric acid, sulphuric acid and acidic thiourea were investigated during the stripping process. The stripping performance is illustrated in Figure 6. Sodium hydroxide shows the highest percentage of stripping which is $75 \%$. It indicates that a strong base has the capability to form coordinate bonds with phenol and to strip the phenol molecules from the organic solvent effectively. This is in line with the work of Zidi et al. [20] where an aqueous sodium hydroxide solution effectively stripped the phenol molecules from the organic solvent due to the chemical reaction of phenol and sodium hydroxide. On the other hand, the stripping percentages of thiourea, $\mathrm{NaHCO}_{3}, \mathrm{HCl}$ and $\mathrm{H}_{2} \mathrm{SO}_{4}$ have been found to be lower. This indicates that the phenol-triglyceride complexes' and the phenol-TBP complexes' bonding is strong enough to hinder the reaction of these stripping agents with phenol. Also, the same polarity between the stripping agents and phenol contributed to weak molecular interactions and van der Waal forces between the molecules. The basic reaction of phenol and sodium hydroxide can be described in equation 6 below [15]:

$$
\mathrm{PhOH}+\mathrm{NaOH} \rightarrow \mathrm{PhONa}+\mathrm{H}_{2} \mathrm{O}
$$

In addition, sodium hydroxide, a strong base which provided sodium ions, $\mathrm{Na}$ attracted and reacted with the negative charges of phenol ions. The phenol molecules were converted into sodium phenolate at the organic solvent interface and were retained in the stripped solution [17]. The phenol-triglyceride complexes reacted with the aqueous sodium hydroxide solution, which lead to the formation of sodium phenolate and triglyceride molecules. Meanwhile, the phenol-TBP complexes reacted with the aqueous sodium hydroxide solution, leading to the formation of sodium phenolate, TBP molecules and water. Triglyceride and TBP molecules were expected to retain in the solvent to form complexes with excess phenols [10]. The sodium phenolates formed from the reaction are expected not to diffuse back into the solvent. The reaction is considered irreversible and instantaneous throughout the process as described in equation 7 below [20].

$$
(\mathrm{PhOH} . \mathrm{TBP})_{(\text {org })}+\mathrm{NaOH}_{(\mathrm{aq})} \leftrightarrow \mathrm{PhONa}_{(\mathrm{aq})}+\mathrm{TBP}_{(\text {org })}+\mathrm{H}_{2} \mathrm{O}
$$




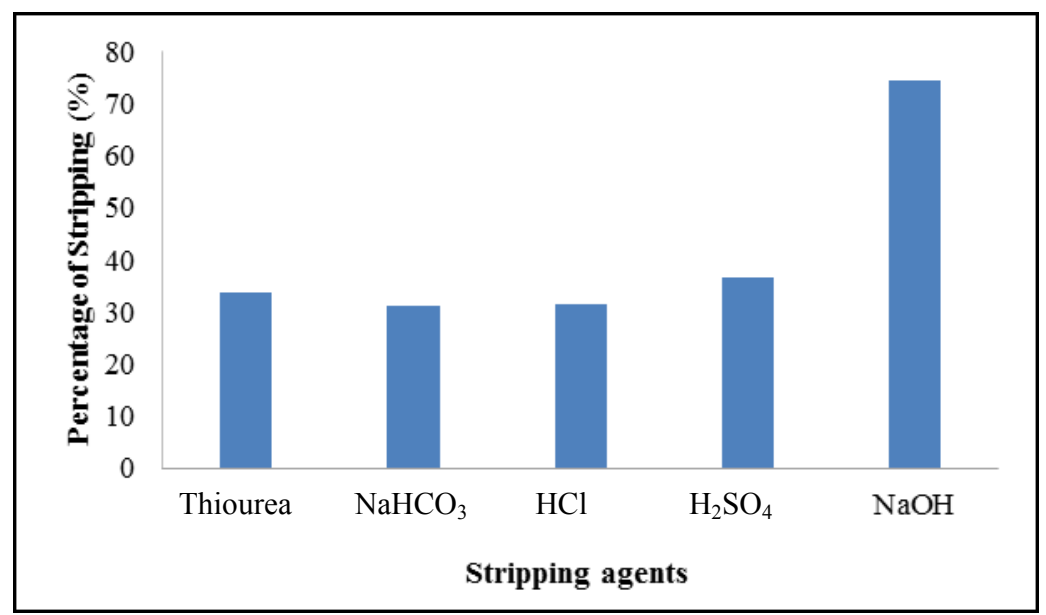

Figure 6. Effect of carrier different stripping agents in liquid-liquid extraction of phenol (experimental condition: $[\mathrm{PhOH}]=300 \mathrm{ppm}$, [stripping agent $]=0.5 \mathrm{M}$, rotation speed $=150 \mathrm{rpm}$, duration $=1$ hour, $\mathrm{T}=25 \pm 1{ }^{\circ} \mathrm{C}$ )

\section{Effect of stripping agent concentration}

The performance of phenol recovery was studied by varying the stripping agent concentration. At the solvent strip interface, phenol reacts with sodium hydroxide to form sodium phenolate and is transported into the stripping phase. The sodium phenolate formed cannot permeate back to the solvent. The concentration of sodium hydroxide plays a crucial role in phenol recovery. The stripping efficiency of phenol was studied in the range of $0.5-2 \mathrm{M} \mathrm{of} \mathrm{NaOH}$ concentration. The results are shown in Figure 7.

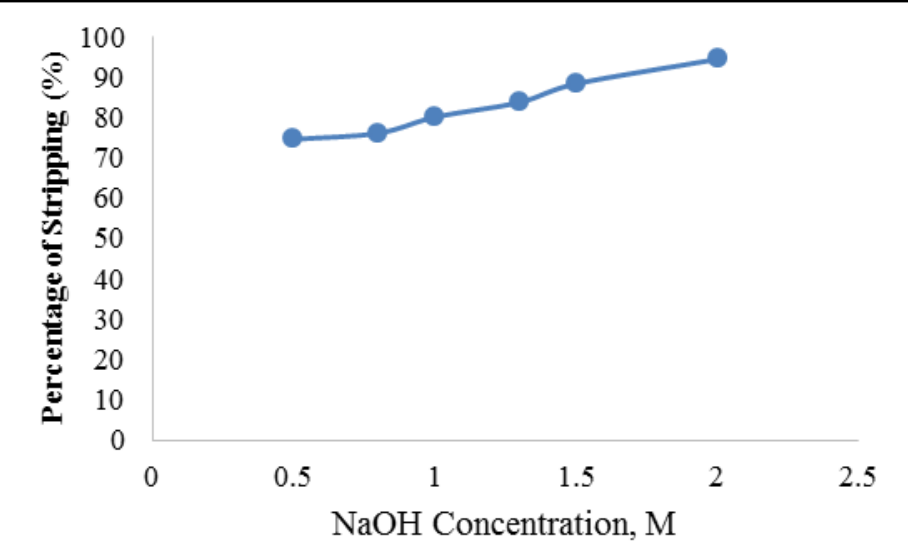

Figure 7. Effect of $\mathrm{NaOH}$ concentration in liquid-liquid extraction of phenol for stripping process (experimental condition: $[\mathrm{PhOH}]=25.76 \mathrm{ppm}$, rotation speed $=150 \mathrm{rpm}$, duration $=1$ hour, $\mathrm{T}=25 \pm 1{ }^{\circ} \mathrm{C}$ )

Based on the results, the rate of phenol transfer is obviously dependent of the concentration of sodium hydroxide within the range studied. According to Venkateswaran and Palanivelu [17], the permeability of solutes depends on the strength of the receiving phase. Below the concentration of $0.5 \mathrm{M}$, the concentration of phenol is insignificant due to the cloudiness of the stripping solution after the process. This problem might be due to the insufficiency of stripping agents to strip out the phenol into the stripping phase. Further increase of $\mathrm{NaOH}$ concentration enhances the stripping percentage of phenol which leads to a greater removal of phenol. It can be seen that by increasing the $\mathrm{NaOH}$ concentration from $0.5 \mathrm{M}$ to $2 \mathrm{M}$, the stripping percentage of phenol increases from $75 \%$ to $94 \%$. Work by Sumalatha et al. [23] reported that the increase of $\mathrm{NaOH}$ concentration leads to an increase in $\mathrm{NaOH}$ to phenol 
molar ratio. This is because a higher concentration of $\mathrm{NaOH}$ provides more $\mathrm{Na}^{+}$ions, thus more phenol ions in the form of complexes are able to be stripped. The more the phenol being stripped will significantly increase the phenol recovery throughout the process.

However, further increases of sodium hydroxide above $2 \mathrm{M}$ will lead to the formation of solid precipitates. It is believed that the solid formed is soap. This is because soap can be produced by hydrolysed fats or oils under basic conditions to form glycerol and a mixture of salts $[24,25]$. The hydrolysis of an ester in a basic solution is called saponification. Basically, saponification can be carried out using a basic sodium or potassium solution. In an ELM process, a high concentration of $\mathrm{NaOH}$ might not be needed because there are various factors that could affect the stripping performance. Figure 8 shows the reaction of triglyceride with sodium hydroxide.

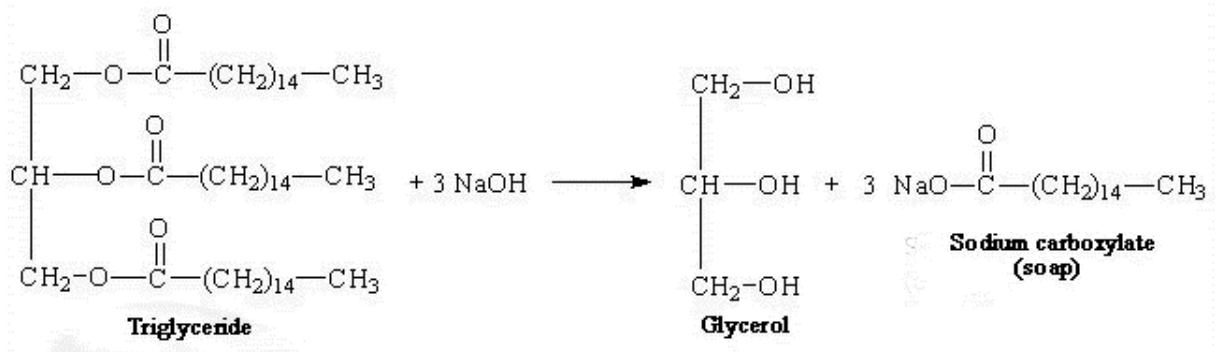

Figure 8. Saponification of triglyceride

By assuming that all sodium hydroxides have reacted with all phenol complexes, the nature of the stripped solute was evaluated by plotting the graph of $\log \mathrm{D}$ versus $\log [\mathrm{NaOH}]$ as shown in Figure 9. The results give a straight line with the line slope of 1.2 which is nearly 1 . Thus, the molar ratio of phenol complex to sodium hydroxide can be assumed to be 1:1, which indicates that one mole of phenol complex requires one mole of sodium hydroxide for a stripping reaction.

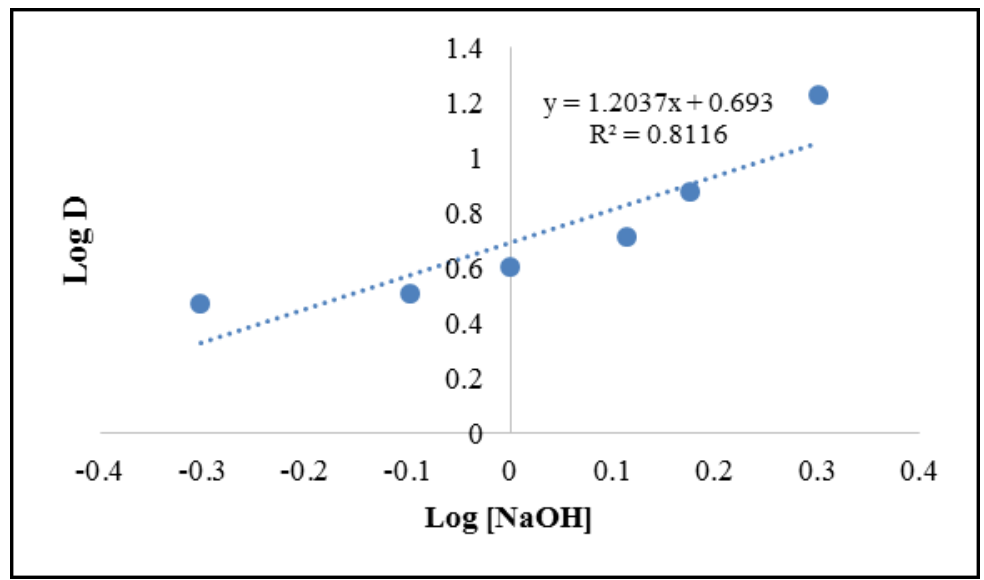

Figure 9. Stoichiometric plot for the equilibrium stripping of phenol using sodium hydroxide as stripping agent

\section{Mechanism of phenol extraction and recovery}

Table 1 shows the results of the liquid-liquid extraction with and without the addition of organic carriers and the recovery performance of phenol. In this research, the composition ratio of palm oil to kerosene (7:3) shows good extraction of phenol, which is $71 \%$ without using a carrier. This indicates that triglycerides present in the oil were able to react with phenol to form phenol-triglyceride complexes. Meanwhile, by adding the carrier (0.1M TBP), phenol extraction increases. This indicates the potential of carriers to enhance the extraction efficiency of phenol, 
which is $86 \%$. TBP is a basic solvating reagent, thus it can react with slightly acidic phenol and form phenol-TBP complex. The TBP structure which contains four oxygen atoms enables the formation of hydrogen bonds with phenol molecule.

In the phenol recovery process, sodium hydroxide shows good stripping performance with up to $94 \%$ of phenol stripped as shown in Figure 7. This proves that sodium hydroxide has the capability of forming stronger polar bonds with phenol molecules. Thus, from the mass balance calculated (Equation 3) based on the amount of phenol extracted and stripped into the stripping phase, the amount of phenol recovered is $81 \%$. This is due to the polarity of phenol which is sufficiently acidic while sodium hydroxide which is known as strong basic compound thus the hydrogen ions of phenol can easily break away from the $\mathrm{OH}$ group and transfer to a base leaving a phenoxide ion. Phenoxide ions then reacted with sodium ions to give a colourless solution that contains sodium phenolate.

Table 1. Performance of phenol extraction and recovery at optimum conditions of component selection

\begin{tabular}{lcc}
\hline Diluent (Phenol: Kerosene) & Carrier & Performance (\%) \\
\hline $7: 3$ & - & $71 \%$ extraction \\
$7: 3$ & $0.1 \mathrm{M} \mathrm{TBP}$ & $86 \%$ extraction \\
\hline
\end{tabular}

Based on results presented, the transfer of phenol through liquid membrane is by two transport mechanisms, which is simple diffusion through kerosene, and carrier-mediated transport through TBP and triglyceride as by functional carriers. Figures 10 and 11 shows the mass transfer mechanisms of phenol. Phenol reacts with the triglyceride present in palm oil to form a phenol-triglyceride complex. On the other hand, phenol reacts with TBP as a carrier to form a phenol-TBP complex. Both complexes react with sodium hydroxide to form sodium phenolate.

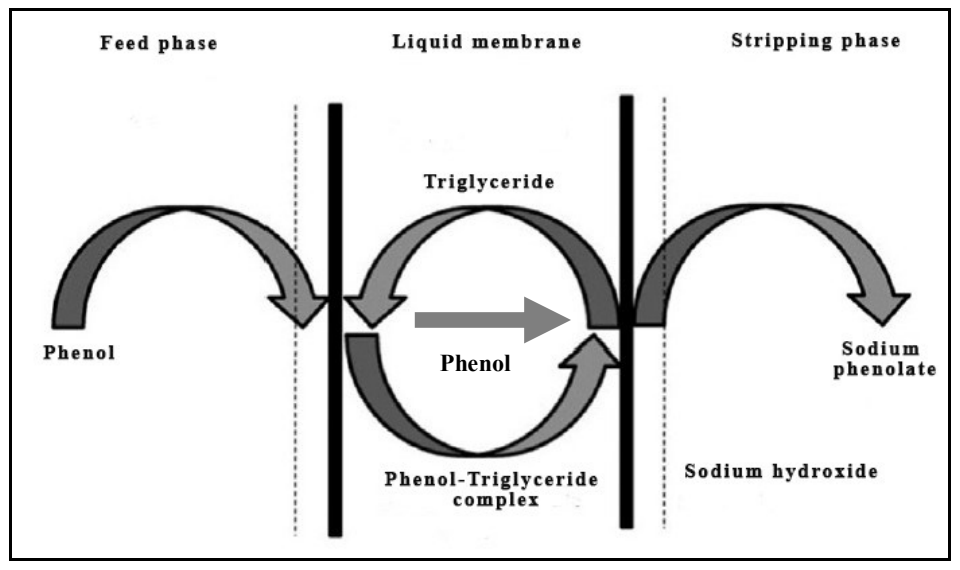

Figure 10. Mass transfer mechanism of phenol-triglyceride complex 


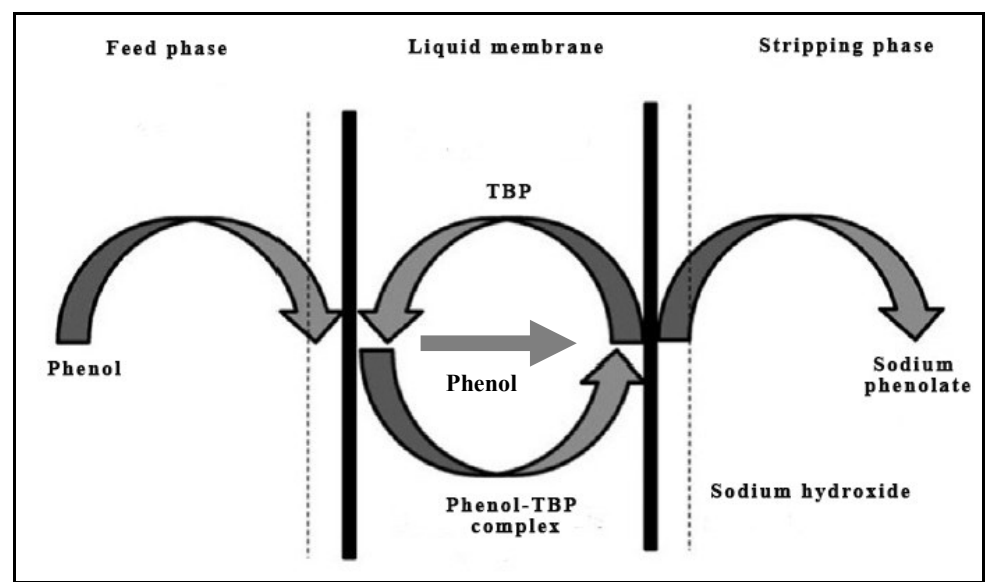

Figure 11. Mass transfer mechanism of phenol-TBP complex

\section{Emulsion liquid membrane process}

The extraction of phenol using ELM was studied after the selection of liquid membrane components had been completed. Figure 12 shows the effect of external feed phase concentration on phenol extraction by ELM process. The results show that the percentage of phenol extraction was highest at the lowest concentration of external feed concentration $(100 \mathrm{ppm})$, where $73 \%$ of phenol was extracted. At lower concentrations, the extraction process was controlled by the external mass transfer that transported into the stripping phase continuously. However, by increasing the external feed concentration, the extraction decreases due to the limitation of triglycerides to form complexes with phenol. Also, the possible swelling and breakage behaviour of emulsion membrane due to osmotic pressure in the system might contribute to the decrement of phenol extraction [26].

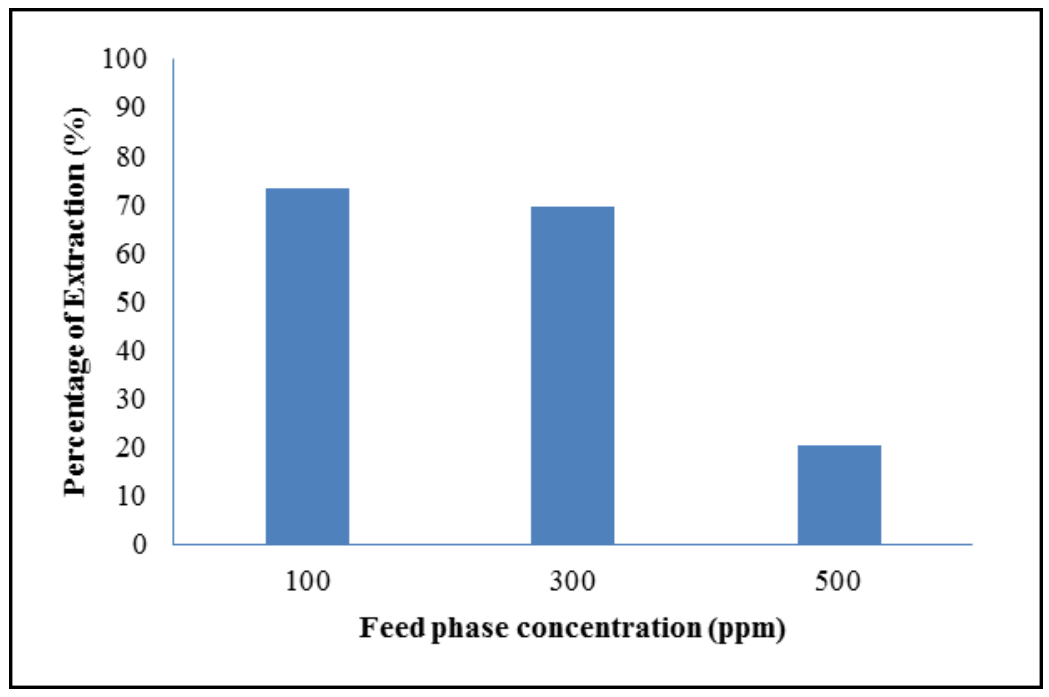

Figure 12. Effect of feed phase concentration in ELM process for phenol extraction (experimental condition: Solvent $=7: 3$ of palm oil to kerosene ratio, Span $80=3 \%,[\mathrm{NaOH}]=0.1 \mathrm{M}$, homogenizer speed $=8000$ $\mathrm{rpm}$, emulsifying time $=5$ minutes, agitation speed $=500 \mathrm{rpm}$, extraction time $=5$ minutes, treat ratio $=$ $\left.1: 3, \mathrm{~T}=25 \pm 1{ }^{\circ} \mathrm{C}\right)$ 
In addition, the transport rate of phenol solutes might decrease largely because of the small capacity of the stripping phase to strip the transported phenol. This attributed to the internal droplets that were readily saturated with the solutes and hindered the diffusion of phenol solutes across the membrane. In this study, the extraction process was conducted at a treat ratio of $1: 3$, where $10 \mathrm{ml}$ of emulsion (means that only $7.5 \mathrm{ml}$ of organic solvent was used) was used to extract phenol from $100 \mathrm{ml}$ of simulated waste solution. Results show that the ELM process was able to extract phenol without using a large amount of solvents and stripping agents. In this study, the extraction percentage during the LLE process using a 7:3 palm oil to kerosene ratio was $71 \%$ while the extraction percentage from the ELM process was $69 \%$. It shows that almost $90 \%$ of organic solvents can be saved for other extraction cycles.

\section{Conclusion}

The liquid-liquid extraction of phenol offers one of the simplest methods as a preliminary study of the emulsion liquid membrane process. Palm oil to kerosene ratio of $70: 30$ was able to extract $71 \%$ of phenol from a simulated aqueous wastewater, which shows a great potential of palm oil as a green solvent. An addition of $0.1 \mathrm{M}$ tributyl phosphate (TBP) increased the extraction efficiency to $86 \%$ and prevented the formation of a third phase during the experiment. Sodium hydroxide is a good stripping agent for phenol recovery and $2 \mathrm{M}$ of $\mathrm{NaOH}$ was able to recover more than $80 \%$ of phenol. The results also show the capability of ELM to extract phenol from wastewater with minimum usage of organic solvent.

\section{Acknowledgements}

The authors would like to acknowledge the Ministry of Higher Education (MOHE), Universiti Teknologi Malaysia (RU Research Grant; GUP: Q.J130000.2546.12H50), Ministry of Science Technology and Innovation (FRGS: R.J130000.7846.4F949), Centre of Lipids Engineering and Applied Research (CLEAR), Universiti Teknologi Malaysia (UTM) for the facilities supporting this research.

\section{References}

1. Rappoport, Z. (2003). The chemistry of phenols. John Wiley \& Sons Ltd., Chichester.

2. Park, Y., Skelland, A. H. P., Forney, L. J. and Kim, J. H. (2006). Removal of phenol and substituted phenols by newly developed emulsion liquid membrane process. Water Research, 40 (9): 1763 - 1772.

3. Hori, T. S. F., Avilez, I. M., Inoe, K. L., Inoue, L. K. and Moraes, G. (2006). Metabolical changes induced by chronic phenol exposure in matrinxa brycon cephalus (Teleostei chracidae) juveniles. Comparative Biochemistry and Physiology, 143(1): 67-72.

4. Jiao, H., Peng, W., Zhao, J. and Xu, C. (2013). Extraction performance of bisphenol A from aqueous solutions by emulsion liquid membrane using response surface methodology. Desalination, 313: 36-43.

5. Mohammadi, S., Kargari, A., Sanaeepur, H., Abbassian, K., Najafi, A. and Mofarrah, E. (2015). Phenol removal from industrial wastewaters: A short review. Desalination and Water Treatment, 53(8): 2215-2234.

6. Mukherjee, S., Kumar, S., Misra, A. K. and Fan, M. (2007). Removal of phenols from water environment by activated carbon, bagasse ash and wood charcoal. Chemical Engineering Journal, 129(1-3): 133-142.

7. Pan, Y., Li, Z., Zhang, Z., Tong, X. S., Li, H., Jia, C. Z., Liu, B., Sun, C. Y., Yang, L. Y., Chen, G. J. and Ma, D. Y. (2016). Adsorptive removal of phenol from aqueous solution with zeolitic imidazolate framework-67. Journal of Environmental Management, 169: 167-173.

8. Tung, C. C., Yang, Y. M., Chang, C. H. and Maa, J. R. (2002). Removal of copper ions and dissolved phenol from water using micellar-enhanced ultrafiltration with mixed surfactants. Waste Management, 22(7): 695-701.

9. Witek, A., Kotuniewicz, A., Kurczewski, B., Radziejowska, M. and Hatalski, M. (2006). Simultaneous removal of phenols and $\mathrm{Cr}^{3+}$ using micellar-enhanced ultrafiltration process. Desalination, 19(1-3): 111-116.

10. Othman, N., Heng, L. C., Noah, N. F. M., Yi, O. Z., Nasruddin, N. A., Ali, N. and Hamzah, S. (2015). Removal of phenol from wastewater by supported liquid membrane process. Jurnal Teknologi (Sciences \& Engineering), 74(7): 117-121.

11. Urtiaga, A., Gutierrez, R. and Ortiz, I. (2009). Phenol recovery from phenolic resin manufacturing: viability of the emulsion pertraction technology. Desalination, 245(1-3): 444-450.

12. Kislik, V. S. (2010). Liquid membrane: Principles and application in chemical separation and wastewater treatment. Elsevier, Amsterdam. 
13. Othman, N., Mili, N., Idris, A. and Zailani, S. N. (2012). Removal of dyes from liquid waste solution: Study on liquid membrane component selection and stability. In Sustainable Membrane Technology for Energy, Water, and Environment. John Wiley and Sons, USA: pp. $221-229$.

14. Othman, N., Mili, N. and Wong, y. M. (2011). Liquid-liquid extraction of black B dye from liquid waste solution using tridodecylamine. Journal of Environmental and Technology, 4(3): 324-331.

15. Othman, N., Noah, N. F. M., Shu, L. Y., Ooi, Z. Y., Jusoh, N., Idroas, M. and Goto, M. (2016). Easy removing of phenol from wastewater using vegetable oil-based organic solvent in emulsion liquid membrane process. Chinese Journal of Chemical Engineering, 25(1): 45-52.

16. Teng, T. T. and Talebi, A. (2012). Green liquid membrane: Development and challenges. Journal of Membrane Science and Technology, 2(3): 2-3.

17. Venkateswaran, P. and Palanivelu, K. (2006). Recovery of phenol from aqueous solution by supported liquid membrane using vegetable oils as liquid membrane. Journal of Hazardous Materials, 131(1-3): 146-152.

18. Othman, N., Mat, H. and Goto, M. (2006). Separation of silver from photographic wastes by emulsion liquid membrane system. Journal of Membrane Science, 282(1-2): 171-177.

19. Carey, A. F. (2008). Organic Chemistry. McGraw Hill, New York.

20. Zidi, C., Tayeb, R., Ali, M. B. S. and Dhahbi, M. (2010). Liquid-liquid extraction and transport across supported liquid membrane of phenol using tributyl phosphate. Journal of Membrane Science, 360(1-2): 334340 .

21. Cichy, W. and Szymanowski, J. (2002). Recovery of phenol from aqueous streams in hollow fiber modules. Environmental Science \& Technology, 36(9): 2088-2093.

22. Othman, N., Noah, N. F. M., Sulaiman, R. N. R., Abdullah, N. A. and Bachok, S. K. (2014). Liquid-liquid extraction of palladium from simulated liquid waste using phosphinic acid as a carrier. Jurnal Teknologi (Science \& Engineering), 68(5): 41-45.

23. Sumalatha, B., Narayana, A. V., Kumar, K. K., Babu, D. J., Venkateswarulu, T. C. (2016). Phenol removal from industrial effluent using emulsion liquid membranes. Journal of Pharmaceutical Sciences and Research, 8(5): 307-312.

24. Bruice, P. Y. (2006). Essential organic chemistry. Pearson Prentice Hall, Upper Saddle River, New Jersey.

25. Solomons, T. W. G. and Fryhle, C. B. (2011). Organic chemistry. John Wiley \& Sons (Asia) Pte Ltd, Asia.

26. Goyal, R. K., Jayakumar, N. S. and Hashim, M. A. (2011). Chromiium removal by emulsion liquid membrane using $[\mathrm{BMIM}]^{+}[\mathrm{NTF} 2]^{-}$as stabilizer and TOMAC as extractant. Desalination, 278(1-3): 50-56. 